\title{
The Impact of Knowledge Management on Organizational Performance
}

\author{
Hayfa.Y. Abuaddous, Abdullah A.M. Al Sokkar \\ Faculty of Computer Science and Informatics \\ Amman Arab University (AAU) \\ Amman, Jordan
}

\author{
Blaqees I. Abualodous \\ Digital Product Planner \\ Disrupt Technologies \\ Amman, Jordan
}

\begin{abstract}
In today's business, knowledge is considered as a core asset in any organization, even it can be considered as important as technological capital. It is part of human abilities and thus human capital. Knowledge management (KM) is becoming a fad in an increasing way so many organizations are trying to apply it in order to enhance their organizational performance. In this paper, literatures were investigated critically in order to show the real influence of knowledge management and some of its practices on organizational performance. It has been founded that KM including knowledge process and infrastructure capabilities affect positively in a huge manner on all aspects of organizational performance directly or indirectly. In the same vein, there is a huge need to continuously train and educate the learning organizations' CEOs about the importance of KM through group works and training programs.
\end{abstract}

Keywords-Knowledge management; infrastructure capabilities; process capabilities; organizational performance; learning organizations

\section{INTRODUCTION}

In this dynamic competitive world and with the clearly influence of information technology (IT) on the business environment, the need arises to get a competitive advantage amid the vast amount of competitors. It has been noticed that a strong tendency within organizations to consider knowledge and its management as a core asset and valuable concept , where their competitive advantage -which they all aspire tolies in [1]. Knowledge is not just facts and numbers that organizations have on spreadsheets or in maps but rather it concerns the whole human experience acquired through education and working skills and experience [2]. Today's businesses are characterized by a high degree of complexity and that indicates for a more accumulation in knowledge, and for sure this leads to a more difficulty in managing and controlling it in terms of storage, organizing and retrieval.. etc. Correspondingly and according to [3], there is an increasing investment in knowledge management every year, where they have cited in their research, Forrester Research Inc. (2010) found that 20 percent of businesses with small and medium size have the intention to construct Customer Relation Management (CRM) or information and knowledge management tools in 2010 or later in North America and Europe. Therefore, we can induce that organizations are strongly starting to believe in Knowledge Management (KM) as a chance to achieve what the majority of them strive for. Logically, when organizations discuss all of the above, it is mainly prompt to improve their performance and the development of decision-making processes and thus to increase profitability and sustainability in today's global markets, and perhaps to get the knowledge capability that enhance the effective management and effective flowing for information and knowledge inside the business [4].

This paper will focus on evaluating the impact of knowledge management and its resources on the organizational performance in order to reach competitive advantages. Besides, this paper will also aim to provide the reader with an overview of knowledge management, and learning organizations.

This paper is organized as follows: the first section of the literature presents an overview of knowledge management; the second section gives an overview to the knowledge management and its impact on organizational performance. The third section will address the learning organizations and how knowledge management will affect them. Finally, future work and conclusion are presented..

\section{AN OVERVIEW OF KNOWLEDGE MANAGEMENT AND ITS CAPABILITIES}

The knowledge that organizations possesses is one of the most important assets that helps them in attaining competitive advantage, even in some cases, it becomes more important than the financial resources and all other tangible assets [2]. With this in mind, knowledge management has become an attractive subject for research and studies in the last twenty years [5] including this research. It can be precisely defined as "the process of capturing information and experience of individuals and the organization -which is available in databases, on paper, or even in people's intellect - and distributing it to wherever it can produce benefit" [6]. Additionally, knowledge management can be attributed as a portfolio of strategies and activities that is related to the process of acquiring, transferring, and sharing knowledge with all organization's people [7]. Researchers noticed that most of their respondents are well educated about knowledge management [7], while others argue that there is unexpected level of misunderstanding to the real knowledge management and its real importance [6]. Above all, the strongly need for an effective implementation to knowledge management arises from the organizations' need to achieve goals such as establishing a competitive advantage to amid the current globalization, also, adapting the organizations with constantly changes and build involved workforce as well as increasing the productivity amid to a highly turnover and downsizing [12]. 
Author in [12] considered knowledge management as a technique that uses the values of knowledge resources in order to enhance the performance for both organizations and employees. They also focus on its ability in facilitating the process of attaining data and information on the needed time, and in improving both strategic and tactical operational activities needed to attain organizational goals. From the theoretical point of view, the components of the knowledge management are (people, processes, technology, culture and structure) and those are the foundation of the knowledge management system [5], where literatures acknowledged that knowledge management determines the knowledge flow inside firms in four steps inside each defined process, which are knowledge creation, retention, transfer, and utilization [2], [6], [8]. Other research added another step titled with knowledge internalization [9]. All the above mentioned activities can be conducted in the organization with relatedness to knowledge management and they can be defined as knowledge management practices and that may include locating, sharing, creating and encouraging through openness culture [10], [11]. Knowledge management may in some cases be affected by demographic characteristics of the organization's employees in a highly manner [7]. Usually, when talking about the knowledge capability of a firm, we can distinguish it into two types of capabilities including firm's knowledge infrastructure capability (e.g., technology infrastructure, organizational structure, and culture) and the firm's knowledge process capability or knowledge management enablers (e.g., knowledge acquisition, conversion, application and protection) [9]. The first and the second comprise the knowledge management capabilities. While [3] stressed the importance of the nature of knowledge capabilities, so that many organizations can include different levels and combinations of knowledge enablers and processes construct the knowledge capability together. Knowledge process capabilities affected positively by collaboration, culture, the support of both top management and information technology. In addition, it is affecting positively- in combination with creative organizational learning- on the organizational performance [8].

When talking about knowledge management we have to mention knowledge management system that emerged with the revolution of ICT and of course automate and the ease of all what managers strive to do through knowledge management. Knowledge management systems (KMS) can be defined as "the planned workplace linkage of specific process steps or domains within an organization. A KMS allows an organization to systematically manage knowledge in order for its workforce to acquire, create and use knowledge to innovate and compete in the marketplace" [5]. Author in [12] portrayed that KMS is comprised from subcomponents including repositories, collaborative platforms, networks, and culture. Also, they considered that building KMS without a robust design will lead to failures. Researchers address that in order to implement an effective knowledge management or even knowledge management system many initiatives need to be done, for example, it is important to take into account the necessary support services to create a supportive environment for knowledge and learning, and linking operations with technology and culture. More importantly, the support of senior management in consolidation of building knowledge management and its related systems and in spreading the culture of knowledge sharing need to be taken under consideration [2], [5], [9].

\section{KM AND ORGANIZATIONAL PERFORMANCE}

Organizational performance (OP) means to what extent the organizational goals and objectives can be achieved [13]. Many empirical and conceptual studies were conducted to test the relationship between $\mathrm{KM}$ and $\mathrm{OP}$ which are summarized in Table I. [4] Investigated the organizational impact of knowledge management practices. The study argued that it is expected that knowledge management practices including (communication, the ability to create new knowledge, acquisition, policies and strategies of KM, and training) affect organizational performance dimensions which include (financial performance, new product success, customer satisfaction, market share) in a positive way among all the dimensions. However, it was revealed that the highest impact was on the success of a new product, which is one of the OP dimensions, and the training was the strongest affecting dimension on OP.

In order to help organizations including academic ones (e.g., Universities) to correctly choosing the strategies for investing in knowledge resources, an empirical study was conducted in the Isfahan universities in Iran, presented that knowledge management resources such as organizational structure and knowledge application are positively affecting OP while other resources such as technology and knowledge conversion are not [1]. It is likely to address that KM strategy could include knowledge transfer concentration, open mindedness orientation, skill sharing and integrated value knowledge [13]. The most significant positive relationships from the whole KM processes performance indicators are factor strategy and leadership, among knowledge management enablers [9]. On the other hand, other similar studies were conducted to reveal the influence of $\mathrm{KM}$ resources on organizational performance with the same dimensions. The results were supported along with organizational structure and knowledge application and weren't the case with as technology and knowledge conversion [14], [15]. With this in mind, we can induce that not all KM resources contribute directly or positively on OP, in other words, each resource is not linked to performance, rather as a composed. It has been found that a non-expected percentage of employees have no interest in knowledge sharing and retrieving, and most of them prefer to depend on their own knowledge and intuition [6]. Since the culture can be considered as a practice of KM beside processes, human capital, and strategy, there is a strong need to construct the culture to ease the process of sharing knowledge between employees. Other researchers also address that wellconstructed culture will lead to support knowledge management process and thus improving the organizational performance [16]. Therefore, they improved the conceptual framework under the name of PICS that aggregate the last enablers for KM effectiveness. Many other factors were found to have heavy effects on organizational performance such as competent competitive advantage, operation improvement, and potential growth. Knowledge management strategy affected the last factors significantly in clothing manufacturing in Thailand and thus it affects OP in a positive way [13]. Although they 
found that, there is no significant relationship between KM practices and financial performance, researchers has also found that they can generalize another rule; There is an existence of a direct significant relationship between KM practices and Organizational performance which includes the financial performance [10]. Fig. 1 is a similar model illustrating the idea of the study.

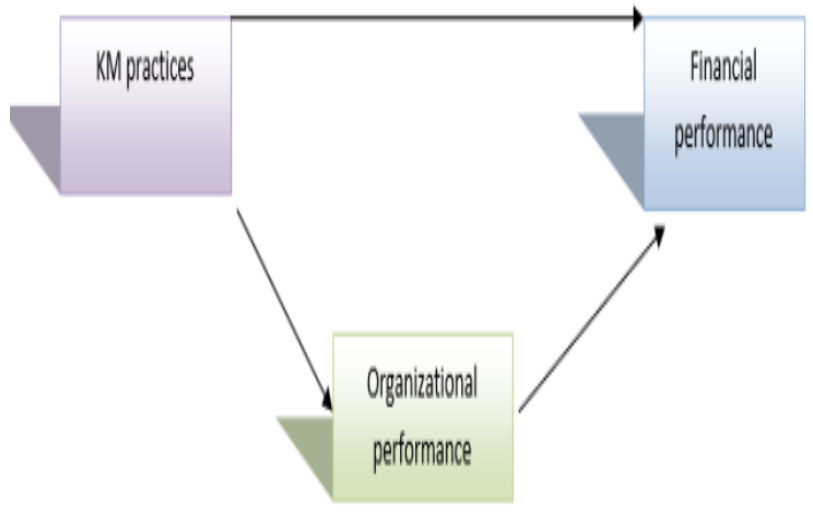

Fig. 1. Research model.

Author in [6] focused on the engineering field; he indicated that knowledge management systems have a significant effect on the effectiveness of strategic decisions that will lead to a better organizational performance. While in [11] focused on banking sector and argued that organizations need to develop their knowledge management processes in order to reach better decisions creations and thus a better organizational performance. They found that there is a significant impact on decision making related to knowledge management practices including what we have mentioned previously (IT infrastructure, HR, shared knowledge and culture).

\section{KM AND LEARNING ORGANIZATIONS}

Not all organizations are learning organizations (LO) although every organization can continuously learn. Rather, every learning organization is any organization that uses the managed knowledge systematically in order to continuously aggregate the best knowledge and to construct its long-term memory [17]. Those organizations arrived to this level due to their employees, where learning depends always on them [7].

TABLE I. SUMMARIZATION OF REVIEWED LITERATURES

\begin{tabular}{|l|l|l|l|}
\hline Article & The study & $\begin{array}{l}\text { Methodology and } \\
\text { Hypothesis }\end{array}$ & Findings \\
\hline Kharabsheh, et al \\
(2012), [4] & $\begin{array}{l}\text { KM practices } \\
\text { and its impact } \\
\text { on OP in } \\
\text { Jordanian } \\
\text { pharmaceutical } \\
\text { firms }\end{array}$ & $\begin{array}{l}\text { Using } \\
\text { questionnaire } \\
\text { survey. Data } \\
\text { gathered from 13 } \\
\text { pharmaceutical } \\
\text { companies in } \\
\text { Jordan. 11 positive } \\
\text { hypothesis }\end{array}$ & $\begin{array}{l}\text { All hypothesis } \\
\text { were } \\
\text { supported. }\end{array}$ \\
\hline $\begin{array}{l}\text { Fattahiyan, et al } \\
\text { (2012), [1] }\end{array}$ & $\begin{array}{l}\text { Study of } \\
\text { relationship } \\
\text { between KM } \\
\text { enablers and }\end{array}$ & $\begin{array}{l}\text { Using } \\
\text { questionnaire } \\
\text { gathered from } \\
\text { 1554 randomly }\end{array}$ & $\begin{array}{l}\text { Some of them } \\
\text { were } \\
\text { supported, } \\
\text { others were }\end{array}$ \\
\hline
\end{tabular}

\begin{tabular}{|c|c|c|c|}
\hline & $\begin{array}{l}\text { processes with } \\
\text { OP in Isfahan } \\
\text { universities } \\
\text { faculty } \\
\text { members } \\
\end{array}$ & $\begin{array}{l}\text { selected members. } \\
9 \text { positive } \\
\text { hypothesis }\end{array}$ & not. \\
\hline $\begin{array}{l}\text { Bhatti, et al } \\
\text { (2011), [16] }\end{array}$ & $\begin{array}{l}\text { The affect of } \\
\text { KM practices } \\
\text { on OP }\end{array}$ & $\begin{array}{l}\text { Conceptual study } \\
\text { with } 2 \text { general } \\
\text { recommended } \\
\text { hypothesis }\end{array}$ & $\begin{array}{l}\text { Recommend } \\
\text { PICS model } \\
\text { will be tested } \\
\text { in the future } \\
\text { on local } \\
\text { service } \\
\text { industry }\end{array}$ \\
\hline $\begin{array}{l}\text { Janepuengporn \& } \\
\text { Ussahawanitchakit } \\
\text { (2011), [13] }\end{array}$ & $\begin{array}{l}\text { The impact of } \\
\text { KM strategy on } \\
\text { OP in clothing } \\
\text { manufacturing } \\
\text { business in } \\
\text { Thailand }\end{array}$ & $\begin{array}{l}\text { Using } \\
\text { questionnaire } \\
\text { survey gathered } \\
\text { from the clothing } \\
\text { manufacturing } \\
\text { sample. } 15 \\
\text { positive hypothesis }\end{array}$ & $\begin{array}{l}\text { All hypothesis } \\
\text { were } \\
\text { supported. }\end{array}$ \\
\hline $\begin{array}{l}\text { Emadzade, et al } \\
\text { (2012), [14] }\end{array}$ & $\begin{array}{l}\text { KM } \\
\text { capabilities and } \\
\text { OP }\end{array}$ & $\begin{array}{l}\text { Using a } \\
\text { questionnaire } \\
\text { gathered from } 245 \\
\text { small size business } \\
\text { owners and } \\
\text { managers in } 86 \\
\text { firms in Isfahan. } 9 \\
\text { positive hypothesis }\end{array}$ & $\begin{array}{l}\text { Some of them } \\
\text { were } \\
\text { supported , } \\
\text { others were } \\
\text { not. }\end{array}$ \\
\hline $\begin{array}{l}\text { Mills \& Smit } \\
\text { (2010), [15] }\end{array}$ & $\begin{array}{l}\mathrm{KM} \text { and } \mathrm{OP}, \\
\text { decomposed } \\
\text { view }\end{array}$ & $\begin{array}{l}\text { survey data from } \\
189 \text { managers and } \\
\text { structural } \\
\text { equation modeling }\end{array}$ & $\begin{array}{l}\text { Some of them } \\
\text { were } \\
\text { supported, } \\
\text { others were } \\
\text { not. }\end{array}$ \\
\hline $\begin{array}{l}\text { Zack, et al (2009), } \\
{[10]}\end{array}$ & $\mathrm{KM}$ and $\mathrm{OP}$ & $\begin{array}{l}\text { Exploratory } \\
\text { analysis, literature } \\
\text { revealed } 12 \mathrm{KM} \\
\text { practices whose } \\
\text { performance } \\
\text { impact was } \\
\text { assessed by a } \\
\text { questionnaire of } \\
\text { business firms. }\end{array}$ & $\begin{array}{l}\text { Some of them } \\
\text { were } \\
\text { supported, } \\
\text { others were } \\
\text { not. }\end{array}$ \\
\hline Но (2009), [9] & $\begin{array}{l}\text { KM enablers } \\
\text { and OP }\end{array}$ & $\begin{array}{l}\text { Exploratory } \\
\text { analysis, literature } \\
\text { reviews, } 3 \\
\text { hypothesis }\end{array}$ & Supported \\
\hline $\begin{array}{l}\text { Mills \& Smit } \\
\text { (2010), [3] }\end{array}$ & $\begin{array}{l}\mathrm{KM} \text { and } \\
\text { performance }\end{array}$ & $\begin{array}{l}\text { internet-based } \\
\text { survey on } 120 \\
\text { responder in } \\
\text { company adapting } \\
\text { KMS with } 7 \\
\text { hypothesis } \\
\end{array}$ & Supported \\
\hline $\begin{array}{l}\text { Shannak (2010). } \\
\text { [6] }\end{array}$ & $\begin{array}{l}\text { KBSs support } \\
\text { for strategic } \\
\text { decision }\end{array}$ & $\begin{array}{l}\text { Using a } \\
\text { questionnaire in } \\
\text { engineering offices } \\
\text { in Jordan }\end{array}$ & Supported \\
\hline $\begin{array}{l}\text { Mohammed and } \\
\text { Jalal (2011), [11] }\end{array}$ & $\begin{array}{l}\text { KMSs support } \\
\text { for decision } \\
\text { making process }\end{array}$ & $\begin{array}{l}\text { Using a } \\
\text { questionnaire in } \\
\text { banking sector,4 } \\
\text { main hypothesis }\end{array}$ & Supported \\
\hline $\begin{array}{l}\text { Frigidian, C. \& } \\
\text { Harris, [18] }\end{array}$ & $\begin{array}{l}\text { Knowledge } \\
\text { management } \\
\text { support to } \\
\text { product } \\
\text { development }\end{array}$ & $\begin{array}{l}\text { Literature review, } \\
\text { case study and } \\
\text { process modeling } \\
\text { using IDEFO } \\
\text { technique }\end{array}$ & $\begin{array}{l}\text { Develop } \\
\text { knowledge } \\
\text { management } \\
\text { framework }\end{array}$ \\
\hline
\end{tabular}

When employees both understand and apply the captured knowledge, then they are learning and eventually those employees are constructing the learning organizations. Learning organizations know exactly how to adapt itself with changes quickly among all levels including developing a 
product, how they response to their customers, and how they manage their human capital [19], [20]. Author in [2] discussed that KM activities are strongly linked to LOs, but they presented that private sector organizations have extremely better processes among all dimensions of LO in comparison with public sector organizations. Researchers portrayed the relationship between knowledge management dimensions discussed above and learning organizations in seven sub relations. LO strategy and vision affected positively by KM processes and leadership, work practices in LO affected positively by KM culture, technology and leadership, and also the culture of LO affected positively by KM culture. In addition, the structure of information and knowledge flow influenced positively by KM process, culture and technology, LO's processes improvement affected positively again by KM process, culture, but also measurement. As well as, the KM process, culture, and leadership affecting positively training and development in LO, and finally KM leadership and measurement affecting positively both reward and recognition in learning organization [2]. Table II inserted to show this supported study's details.

TABLE II. CHAWLA \& JOSHI [2] STUDY's SUMMARIZATION

\begin{tabular}{|c|c|c|c|}
\hline Article & The study & $\begin{array}{l}\text { Methodology } \\
\text { and Hypothesis }\end{array}$ & Findings \\
\hline $\begin{array}{c}\text { Chawla and } \\
\text { Joshi (2011), } \\
\text { [2] }\end{array}$ & $\begin{array}{l}\text { The impact of } \\
\text { KM on Los, } \\
\text { comparison } \\
\text { between private } \\
\text { and public } \\
\text { sector } \\
\text { organizations }\end{array}$ & $\begin{array}{l}\text { Using surveys } \\
\text { among } 51 \\
\text { executives } \\
\text { among } 16 \text { private } \\
\text { and public firms } \\
\text { in India. } \\
7 \text { Hypothesis. }\end{array}$ & Supported \\
\hline
\end{tabular}

Author in [7] conducted a survey with 180 managers and engineers to test the impact of knowledge management on learning organizations. The major findings revealed that the higher level of information, knowledge application, and KM processes will clearly help learning organizations in enhancing their performance as a whole including the innovation and the process of decision-making. They advised to conduct this empirical study yearly in each organization in order to evaluate all new practices so that organizations can learn.

\section{FUTURE WORK}

As a future direction for this research, an empirical study will be conducted to involve a survey of Jordanian manufacturing that implement knowledge management systems. In order to test the most critical success factors (CSFs) that affect implementing knowledge management systems (KMSs) in the manufacturing Jordanian environment. This study may also incorporate user's factors that may affect (users' perceptions towards the use and implementation of knowledge management system in manufacturing organizations, user's satisfaction, and user's training). In order to prepare the final Critical Success Factors in Jordanians manufacturing, this study will be tested with the following three theoretical hypotheses:

H1: There is a significant impact of user's satisfaction on KMSs implementation success.

H2: There is a significant impact of user's perception of ease of use on KMSs implementation success.
H3: There is a significant impact of user's training on KMSs implementation success.

\section{CONCLUSION}

Nowadays, knowledge is considered as an essential asset in any organization. Thus, many organizations are trying to apply Knowledge management in order to improve their organizational performance. This article has reviewed the positive impact of knowledge management and some of its practices on organizational performance. Many studies have concluded that $\mathrm{KM}$ is the main reason to business growth. Thus, it is good to invest in KM resources to attain organizational performance improvement, since KM resources and practices are related directly and indirectly to it when they are implemented effectively. In order to implement an effective knowledge management system, the support of senior management in consolidation of building knowledge management and in spreading the culture of knowledge sharing need to be taken under consideration. Furthermore, there is a huge need to continuously train and educate the organizations' CEOs about the importance of KM through group works and training programs.

\section{REFERENCES}

[1] S. Fattahiyan, R. Hoveida, S. Siadat, and H. Tallebi, "Study Of Relationship Between Knowledge Management Enablers And Processes With Organizational Performance", Interdisciplinary Journal Of Contemporary Research In Business, Vol.4 (4), pp. 36-44, 2012.

[2] D. Chawla, and H. Joshi, "Impact of Knowledge Management on Learning Organization in Indian Organizations-A Comparison", Knowledge and Process Management, Vol. 18(4), pp. 266-277,2011.

[3] A. Mills, and T. Smith," Knowledge Management And Organizational Performance: A Decomposed View", Journal Of Knowledge Management, Vol. 15 (1), pp. 156-171, 2010.

[4] R. Kharabsheh, I. Magableh, and S. Sawadha, "Knowledge Management Practices (KMPs) and Its Impact on Organizational Performance in Pharmaceutical Firms",.European Journal of Economics, Finance and Administrative Sciences, Vol.48, pp. 6-15, 2012.

[5] E. Fibuch, and CW. Vanway, "What Is a Knowledge Management System and Why Should Care?”, PEJ, Vol. 37(5), pp.34-39,2011.

[6] R. Shannak, "Knowledge-based Systems Support for Strategic Decisions". European Journal of Economics, Finance and Administrative Sciences, Vol.21 (2010), pp. 7-20, 2010.

[7] U. Aktharsha, and H. Anisa, "Knowledge Management System and Learning Organization: An Empirical Study in an Engineering Organization". The IUP Journal of Knowledge Management, Vol. IX( 2), pp.27-43, 2011.

[8] S. Lee, B. Kim, and H. Kim, " An Integrated View Of Knowledge Management For Performance", Journal Of Knowledge Management, Vol.16 (2), pp. 183-203. 2012

[9] C. Ho, "The Relationship Between Knowledge Management Enablers And Performance", Industrial Management \& Data Systems. Vol. 109 (1), pp. 98-117, 2009.

[10] M. Zack, J. McKeen, and S. Singh, "Knowledge Management And Organizational Performance: An Exploratory Analysis". Journal Of Knowledge Management, Vol. 13 ( 6), pp. 392-409, 2009.

[11] W. Mohammed, and A. Jalal, "The Influence of Knowledge Management System (KMS) on Enhancing Decision Making Process (DMP)", International Journal of Business and Management, Vol.6 (8), pp.216-229, 2011.

[12] R. Gopal, and P. Joy. "Creation of Knowledge Management System". Advances In Management, Vol. 4(11), pp.7-14, 2011.

[13] K. Janepuengporn, and P. Ussahawanitchakit, " The Impacts Of Knowledge Management Strategy On Organizational Performance: An Empirical Study Of Clothing Manufacturing Businesses In Thailand". 
International Journal Of Business Strategy, Vol. 11 (1), pp. 92-109, 2011.

[14] D. Emadzade, B. Mashayekhi, and E. Abdar, "Knowledge management capabilities and organizational performance", Interdisciplinary Journal Of Contemporary Research In Business, Vol 3 ( 11), pp. 781-790, 2012.

[15] A. Mills, and T. Smith., "29P. Exploring the Impact of Knowledge Management Capabilities on Organizational Effectiveness", CONF-IRM 2010 Proceedings. 35, 2010.

[16] https://aisel.aisnet.org/confirm2010/35

[17] W. Bahatti, A. Zaheer, and K. Rehman, "The effect of knowledge management practices on organizational performance: A conceptual study", African Journal of Business Management, Vol. 5(7), pp. 28472853, 2011.

[18] C. Frigidian, and A. Harris. "Knowledge Management To Support Product Develonmant In F 1 1 D $\wedge 11$ E^rming Environment", Int J Adv Manuf Technol, Vol.57 (5), pp 585-596 pp.585-596, 2011.

[19] A. Al Sokkar, and E. Law, "Validating an episodic UX model on online shopping decision making: A survey study with B2C e-commerce". In Proceedings of the 5th ACM SIGCHI symposium on Engineering interactive computing systems (pp. 297-306). ACM, 2013.

[20] T. Orehovački, A. Al Sokkar, J. Derboven, A, Khan, "Exploring the Hedonic Quality of Slow Technology". In: CHI 2013 workshop on Changing Perspectives of Time in HCI, 2013. 